\title{
An Evaluation of the Pathways of Metabolism of Glucose, Gluconate and 2-Oxogluconate by Pseudomonas aeruginosa by Measurement of Molar Growth Yields
}

\author{
By I. MACKECHNIE* AND E. A. DAWES \\ Department of Biochemistry, University of Hull
}

(Accepted for publication 22 October 1968)

\section{SUMMARY}

Pseudomonas aeruginosa, ATCC 9027, was grown in a simple ammonium salts medium with limiting glucose, gluconate or 2-oxogluconate as the sole carbon and energy source. There was little difference in molar growth yield between glucose and gluconate but with 2-oxogluconate the yield was signicantly less. Measurement of $Y_{\mathrm{O}_{\mathbf{g}}}$ values (g. dry weight of cells produced/mole of oxygen consumed) during growth on the three substrates indicated most efficient oxygen utilization with 2-oxogluconate. The results are discussed in relation to the relative metabolic importance of the various pathways of of glucose metabolism in the organism.

\section{INTRODUCTION}

Several initial pathways of glucose metabolism are possible in Pseudomonas aeruginosa. The presence of a direct oxidative pathway via gluconate and 2-oxogluconate has been recognized for many years (for a review, see De Ley, I960) and evidence has been presented that these oxidations are not linked to nicotinamide or flavin nucleotides (Ramakrishnan \& Campbell, 1955; Campbell, Ramakrishnan, Linnes \& Eagles, 1956). The presence of enzymes characteristic of phosphorylative pathways, such as hexokinase, gluconokinase and glucose 6-phosphate dehydrogenase, has also been demonstrated in cell-free extracts of glucose-grown $P$. aeruginosa (Claridge \& Werkman, I953, 1954). In the present investigation, molar growth yield determinations (Bauchop \& Elsden, 1960) were carried out with glucose, gluconate and 2-oxogluconate as the sole carbon and energy sources in an attempt to gain some insight into the relative metabolic importance of the various pathways, the assumption being made that glucose metabolism via the direct oxidative pathway would make less energy available to the organism than a pathway via glucose 6-phosphate and 6-phosphogluconate in which the oxidative step is nicotinamide nucleotide-linked. Campbell et al. (I956) did report that when $P$. aeruginosa, strain ATCC 9027, was grown on limiting equimolar amounts of glucose, gluconate or 2-oxogluconate identical growth yields were obtained, and they concluded that no energy was gained in the oxidative steps from glucose to 2-oxogluconate. Unpublished observations in our laboratory with a different strain of $P$. aeruginosa, $2 \mathrm{~F}_{32}$, indicated that there were some differences in molar growth yield with the three substrates and the present work was undertaken to re-examine the observations of Campbell et al. (1956) with strain ATCC 9027.

* Present address: Unilever Research Laboratory, Colworth House, Sharnbrook, Bedford. 


\section{METHODS}

Organism. Pseudomonas aeruginosa, strain ATCC 9027, was maintained on nutrient agar slopes at $30^{\circ}$. It was subcultured at monthly intervals and stock slopes were stored at $4^{\circ}$.

Media. For molar growth yield determinations, the following medium was used: $\mathrm{KH}_{2} \mathrm{PO}_{4}, 9$ g.; $\left(\mathrm{NH}_{4}\right)_{2} \mathrm{SO}_{4}, 2$ g. ; nitrilotriacetic acid, 0.48 g.; $\mathrm{Na}_{2} \mathrm{MoO}_{4} .2 \mathrm{H}_{2} \mathrm{O}, 0.004$ g.; the $\mathrm{pH}$ was adjusted to $7 \cdot \mathrm{I}$ with $5 \mathrm{~N}-\mathrm{NaOH}$ and the volume made up to I 1 . with distilled water. Three volumes of this solution were diluted with two volumes of carbon source solution (see below) and $5 \mathrm{ml}$. of each of the following two salts solutions added per litre of complete medium. Salts solution I contained: concentrated $\mathrm{HCl}, 13.4 \mathrm{ml}$; $\mathrm{CaCO}_{3}, 2$ g.; $\mathrm{ZnO}, 0.406$ g. $; \mathrm{FeCl}_{3} .6 \mathrm{H}_{2} \mathrm{O}, 5 \cdot 4$ g. $; \mathrm{MnCl}_{2} \cdot 4 \mathrm{H}_{2} \mathrm{O}, 0.99$ g. $; \mathrm{CuCl}_{2} .2 \mathrm{H}_{2} \mathrm{O}$, $0.17 \mathrm{~g}$.; $\mathrm{CoCl}_{2} .6 \mathrm{H}_{2} \mathrm{O}, 0.238 \mathrm{~g}$. $\mathrm{H}_{3} \mathrm{BO}_{3}, 0.062 \mathrm{~g}$.; distilled water up to I 1. Salts solution 2 contained: concentrated $\mathrm{HCl}, 45 \mathrm{ml}$., $\mathrm{MgO}, 10.08 \mathrm{~g}$; d distilled water up to I 1 . Details of these salt solutions were originally provided by $\mathrm{Mr} \mathrm{D}$. W. Tempest. All carbon sources were sterilized by filtration through a Millipore membrane (Millipore Filter Corporation, Bedford, Massachusetts) and, with the exception of 2-oxogluconate, were added to the medium at $2,3,4$, and $5 \mathrm{~mm}$ final concentration. 2-Oxogluconic acid was prepared by passing a solution of the commercial calcium salt through a column of Dowex 50 cation exchange resin in the hydrogen form. The free acid was eluted from the column with distilled water and its concentration determined by titration against standardized $0.01 \mathrm{~N}-\mathrm{NaOH}$ in a Conway microburette using phenol red as indicator. $\mathrm{CO}_{2}$-free air was bubbled through the titration mixture. The acid was neutralized with $\mathrm{NaOH}$ and added to the medium at known concentrations approximating to those used for the other carbon sources.

Growth experiments. Molar growth yield determinations were carried out at $30^{\circ}$ and $37^{\circ}$ in two ways:

I. In $12.5 \mathrm{ml}$. medium contained in $50 \mathrm{ml}$. Erlenmeyer flasks shaken in reciprocating water baths at 80 strokes $/ \mathrm{min}$. with an amplitude of $\mathrm{I} \cdot 5$ in. Growth was followed turbidimetrically at $570 \mathrm{~m} \mu$ with a Unicam SP 600 spectrophotometer (Unicam Instruments, Cambridge) by using flasks fitted with test-tube side arms. When growth was complete, the cultures were made up quantitatively to $25 \mathrm{ml}$. in volumetric flasks with $0.067 \mathrm{M}$-phosphate buffer, $\mathrm{pH} 7 \cdot \mathrm{I}$, for measurement (see later).

2. In $3 \mathrm{ml}$. medium in Barcroft flasks (without side arms but with centre wells) on the Warburg apparatus. Oxygen consumption was followed until it ceased to be exponential, at which point the flasks were removed and the cultures made up to Io ml. with phosphate buffer prior to measurement. Barcroft flask centre wells contained $0.2 \mathrm{ml}$. of the $\mathrm{CO}_{2}$-buffer, diethanolamine $(60 \%, \mathrm{w} / \mathrm{v})$ containing thiourea $(0.1 \%, w / v)$, a solution based on the reagent of Pardee (I949). The use of $\mathrm{KOH}$ as centre well fluid resulted in extremely long lag phases (often greater than $24 \mathrm{hr}$ ) before growth began. Inocula for growth yield experiments were prepared as follows: the organism was subcultured from a nutrient agar slope into $12.5 \mathrm{ml}$. of medium in which the carbon source concentration was $0.8 \%(w / v)$. Two further subcultures were carried out under these conditions before transfer to a medium in which the carbon source was present in limiting amount $(5 \mathrm{mM})$. The organism was subcultured at least three times in limiting medium before use in growth yield experiments to ensure adequate training of the cells on the particular energy source and no carry-over of unused 
energy source. The organism was not grown on excess 2-oxogluconate but trained through several subcultures on limiting concentrations of 2-oxogluconate, cells grown on gluconate being used for the initial inoculum. Erlenmeyer flasks were inoculated with $0.1 \mathrm{ml}$. and Barcroft flasks with $0.05 \mathrm{ml}$. of a limiting culture ( $5 \mathrm{~mm}$ energy source) which had just reached the stationary phase.

Growth was measured in two ways. In the first, the extinction of suspensions was measured at $570 \mathrm{~m} \mu$ in the Unicam SP 600 spectrophotometer and the dry weight was read from a standard calibration curve relating extinction to bacterial dry weight over the range $0.05-0.5 \mathrm{mg}$. cells $/ \mathrm{ml}$. In the second, a modification of the method of Johnson (1949) for the colorimetric determination of organic matter was used. Cell suspensions were mixed with an equal volume of $0.8 \mathrm{M}$-perchloric acid, in glass centrifuge tubes, centrifuged and washed once with a volume of $0.4 \mathrm{M}$-perchloric acid equal to twice the volume of the original suspension. The precipitates were suspended in $\mathrm{I} \mathrm{ml}$. of distilled water and $3 \mathrm{ml}$. of the oxidizing reagent, $\mathrm{K}_{2} \mathrm{Cr}_{2} \mathrm{O}_{7}(0 \cdot 18 \%$, w/v) in concentrated $\mathrm{H}_{2} \mathrm{SO}_{4}(95 \%, \mathrm{v} / \mathrm{v})$, added. The tubes were closed with glass condensers and heated at $100^{\circ}$ for $20 \mathrm{~min}$. The solutions were cooled, made up quantitatively to Io $\mathrm{ml}$. with distilled water and the extinctions measured at $440 \mathrm{~m} \mu$ against a reagent blank, reduced chemically by addition of $0.2 \mathrm{ml} . \mathrm{Na}_{2} \mathrm{SO}_{3} \cdot 7 \mathrm{H}_{2} \mathrm{O}(20 \%$, w/v). A calibration curve relating extinction at $440 \mathrm{~m} \mu$ to bacterial dry weight over the range $0.1-0.8 \mathrm{mg}$. cells $/ \mathrm{ml}$. was prepared. All spectrophotometric measurements of bacterial growth were made with $4 \mathrm{ml}$. glass spectrophotometer cells with a $\mathrm{I} \mathrm{cm}$. light path. For preparation of calibration curves, large batches of cells were grown to stationary phase at $30^{\circ}$ or $37^{\circ}$ under conditions of forced aeration with limiting glucose $(5 \mathrm{Mm})$ as carbon source. Dry weight measurements were made by heating concentrated cell suspensions to constant weight in a hot air oven at $104^{\circ}$.

Isotopic experiments with $\left[U_{-}{ }^{14} C\right]$ glucose. $30 \mathrm{ml}$. of medium were prepared such that the glucose concentration was $4 \mathrm{mM}$ and its specific activity was $0 \cdot 168 \mu \mathrm{c} / \mu$ mole. This medium was sterilized by membrane filtration and $12.5 \mathrm{ml}$. amounts dispensed into $50 \mathrm{ml}$. Erlenmeyer flasks fitted with side arms. These were inoculated with $0.05 \mathrm{ml}$. of a limiting culture as previously described, stoppered with rubber bungs and incubated until growth was complete. The suspensions were made up quantitatively to $25 \mathrm{ml}$. with distilled water for measurement of turbidity. The radioactivity of $(a)$ the original medium, $(b)$ the cell suspension, and $(c)$ the growth supernatant solution (obtained by centrifuging a sample of the cell suspension at $14,000 \mathrm{~g}$ for $15 \mathrm{~min}$.) was determined by spreading portions ( 0.1 and $0.2 \mathrm{ml}$.) of suitably diluted solutions on clean nickel planchets having an effective raised area of $1 \cdot 77 \mathrm{~cm} .{ }^{2}$ and drying under an infra-red lamp. In $(b)$ and $(c)$ the $\mathrm{pH}$ was adjusted to at least 7.6 with $0.2 \mathrm{~N}-\mathrm{NaOH}$ to prevent loss of steam-volatile acids. All estimations were made at infinite thinness using an Ekco Automatic Scalar, Type N530G, and corrections were applied for background. Counts were collected for a period sufficient to ensure that the counting error was less than $\pm 4 \%$.

Chemicals. Unless otherwise stated, all chemicals were obtained from Hopkin and Williams Ltd., Chadwell Heath, Essex or British Drug Houses Ltd., Poole, Dorset. Wherever possible, A.R. grade reagents were used. Of the growth substrates, glucose was A.R. and sodium gluconate was Laboratory Reagent quality. Calcium 2-oxogluconate was obtained from Nutritional Biochemicals Ltd., Cleveland, Ohio, U.S.A. The purity of the three growth substrates was checked by paper chromatography 
using a modification of the method of Grado \& Ballou (196I). The solvent system was ethyl acetate-pyridine-water saturated with boric acid (60:25:40 by volume). On shaking this separated into two layers and the top layer was used as solvent. Descending paper chromatograms (Whatman No. I) were run for $48 \mathrm{hr}$, and were developed with the benzidine-periodate reagent described by Smith (1961). Each substrate ran as a single spot.

[U-14 $\mathrm{C}]$ Glucose was obtained from the Radiochemical Centre, Amersham, Bucks.

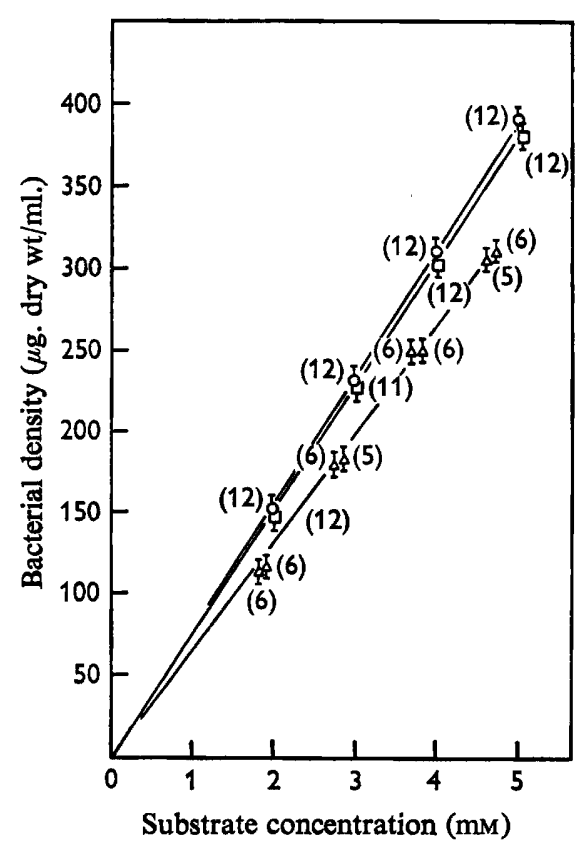

Fig. 1

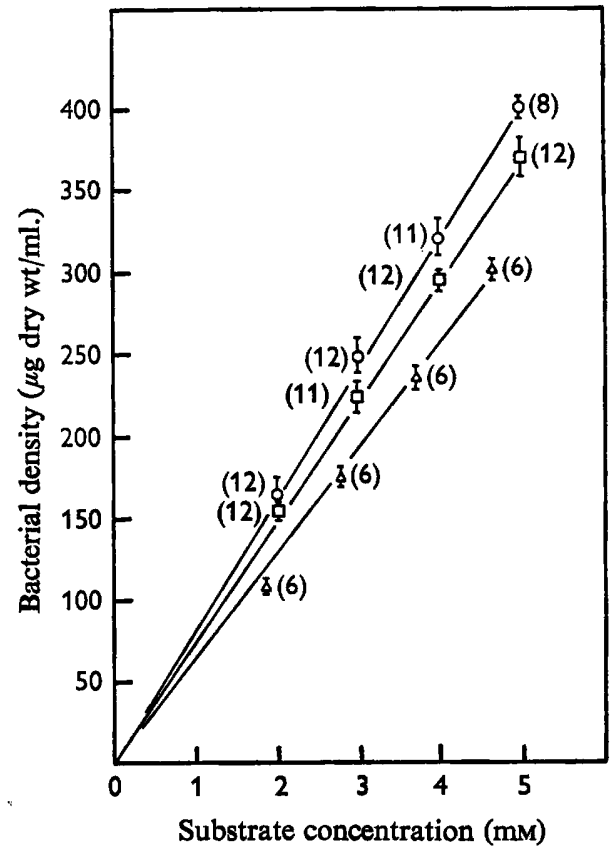

Fig. 2

Fig. I. The relation between growth of $P$. aeruginosa at $30^{\circ}$ and substrate concentration. Growth substrates: $O$, glucose; $\square$, sodium gluconate; $\triangle$, sodium 2-oxogluconate. Each point is the mean of the number of estimations shown in parentheses; the standard deviations from the mean are represented by the heights of the vertical bars.

Fig. 2. The relation between growth of $P$. aeruginosa at $37^{\circ}$ and substrate concentration. Growth substrates: $O$, glucose; $\square$, sodium gluconate; $\triangle$, sodium 2-oxogluconate. Each point is the mean of the number of estimations shown in parentheses; the standard deviations from the mean are represented by the heights of the vertical bars.

\section{RESULTS}

Figure I shows the relation between total growth of the organism at $30^{\circ}$ in open flasks, as measured by extinction, and substrate concentration. Growth was measured over a range of substrate concentrations to ensure that the energy source was the growth-limiting factor. Similar data were obtained for growth at $37^{\circ}$ (Fig. 2). In each case the mean $Y$ values were calculated from the gradients of the straight lines relating growth to substrate concentration and are summarized in Table I. The results obtained using the method for the estimation of total organic matter were plotted in a similar manner and are also recorded in Table $\mathrm{I}$. 
A summary of the results obtained from manometric growth experiments is given in Table 2. The importance of making turbidimetric growth measurements as soon as oxygen consumption ceases to be exponential is illustrated in Fig. 3 for glucose-grown cells at $37^{\circ}$. The experiment was performed at a single glucose concentration (4 mM) by removing flasks for growth measurement at the times indicated by the triangles. The oxygen consumption which occurs at the end of exponential growth is presumably due to the oxidation of endogenous materials and therefore not a reliable indication of the 'growth curve' of the culture. Similar relationships between oxygen consump-

Table I. Summary of molar growth yields obtained with Pseudomonas aeruginosa in open flasks

\begin{tabular}{lccc}
\multicolumn{1}{c}{ Substrate } & $30^{\circ}$ & $37^{\circ}$ & $79(43)$ \\
Glucose & $77(48)^{*}$ & $74(47)$ & $\begin{array}{c}78(34) \\
\text { Turbidimetric }\end{array}$ \\
Sodium gluconate & $75.5(46)$ & $70^{\circ}$ \\
Sodium 2-oxogluconate & $66(46)$ & $64.5(24)$ & -
\end{tabular}

* Molar growth yields are expressed as g. dry weight of organism per mole of substrate; figures in parentheses represent the total number of determinations made for each substrate.

Table 2. Summary of results from manometric growth experiments with Pseudomonas aeruginosa

\begin{tabular}{|c|c|c|c|c|c|c|}
\hline Substrate & $\begin{array}{c}\text { Growth } \\
\text { tempera- } \\
\text { ture }\end{array}$ & $\begin{array}{c}\text { Molar growth } \\
\text { yield } \\
\text { (g./mole) }\end{array}$ & $\begin{array}{c}\text { Percentage } \\
\text { of substrate } \\
\text { oxidized }\end{array}$ & $\begin{array}{c}\text { Mean } \\
\text { generation } \\
\text { time (min.) }\end{array}$ & $\begin{array}{l}\text { Oxygen } \\
\text { consump- } \\
\text { tion } \\
\text { (mole/ } \\
\text { mole of } \\
\text { substrate) } \dagger\end{array}$ & $\begin{array}{l}Y_{\mathrm{og}_{\mathrm{g}}} \text { (g. dry } \\
\text { weight/ } \\
\text { mole of } \\
\text { oxygen } \\
\text { consumed) } \dagger\end{array}$ \\
\hline Glucose & $\begin{array}{l}30^{\circ} \\
37^{\circ}\end{array}$ & $\begin{array}{l}78 \cdot 1 \pm 1 \cdot 5(16) \\
76 \cdot 2 \pm 2 \cdot 0(\mathrm{I} 2)\end{array}$ & $\begin{array}{l}40 \cdot 6 \pm I \cdot 4 \text { (I6) } \\
42 \cdot 6 \pm 1.8 \text { (I2) }\end{array}$ & $\begin{array}{l}77 \cdot 6 \pm 6(15) \\
68 \cdot 9 \pm 8(12)\end{array}$ & $\begin{array}{l}2 \cdot 44 \\
2 \cdot 55\end{array}$ & $\begin{array}{l}32.0 \\
29.9\end{array}$ \\
\hline odium gluconate & $\begin{array}{l}30^{\circ} \\
37^{\circ}\end{array}$ & $\begin{array}{l}75 \cdot 5 \pm 1 \cdot 2(15) \\
73 \cdot 1 \pm 1 \cdot 8(14)\end{array}$ & $\begin{array}{l}40 \cdot 2 \pm I \cdot 4(I 5) \\
4 I \cdot 3 \pm I \cdot 7(I 4)\end{array}$ & $\begin{array}{l}84 \cdot 0 \pm 4 \cdot 4(15) \\
77 \cdot 0 \pm 5 \text { (14) }\end{array}$ & $\begin{array}{l}2 \cdot 21 \\
2 \cdot 28\end{array}$ & $\begin{array}{l}34 \cdot 2 \\
32 \cdot 1\end{array}$ \\
\hline $\begin{array}{l}\text { Sodium } \\
\text { 2-oxogluconate }\end{array}$ & $\begin{array}{l}30^{\circ} \\
37^{\circ}\end{array}$ & $\begin{array}{l}64 \cdot 6 \pm I \cdot 2 \text { (II) } \\
62 \cdot 0 \pm 2 \cdot I \text { (I2) }\end{array}$ & $\begin{array}{l}36 \cdot 0 \pm I \cdot 3(11) \\
36 \cdot 7 \pm 2 \cdot 0(12)\end{array}$ & $\begin{array}{l}90 \cdot 8 \pm 4 \text { (II) } \\
75 \cdot 4 \pm 6 \text { (I2) }\end{array}$ & $\begin{array}{l}1 \cdot 80 \\
1 \cdot 85\end{array}$ & $\begin{array}{l}35 \cdot 9 \\
33 \cdot 8\end{array}$ \\
\hline
\end{tabular}

* Based on the theoretical oxygen consumption for complete oxidation of substrate to $\mathrm{CO}_{2}$ and water.

$\uparrow$ Based on the average values for the percentage of substrate oxidized.

The figures in parentheses represent the number of estimations carried out.

tion and molar growth yield were obtained with gluconate and 2-oxogluconate, also at $4 \mathrm{mM}$ at $30^{\circ}$ and $37^{\circ}$. Oxygen consumption subsequent to cessation of exponential growth and the concomitant drop in molar growth yield were always more marked at $37^{\circ}$. The results in Table 2 are expressed in terms of molar growth yields and also as the grams dry weight of cells produced per mole of oxygen consumed $\left(Y_{\mathrm{O}_{2}}\right)$. The $Y_{\mathrm{O}_{2}}$ concept was introduced by Whitaker and Elsden (1963) to compare yields of a number of organisms as a function of oxygen consumption under conditions where the energy source concentration was the growth-limiting factor. Of relevance to the problem here were their observations on $Y_{\mathrm{O}_{2}}$ as a measure of the efficiency of oxygen utilization during growth, e.g. they shower that when Pseudomonas fluorescens was 
grown on benzoate or nicotinate, the $Y_{\mathrm{O}_{2}}$ values were less than those obtained when the organism was grown on equimolar mixtures of the products of ring fission, in agreement with the view that the oxygen used for ring fission does not participate in oxidative phosphorylation. The use of $Y_{\mathbf{O}_{2}}$ as a measure of the efficiency of oxygen utilization during glucose metabolism by $P$. aeruginosa will be discussed later.

To measure the percentage assimilation of glucose by the cells during growth and

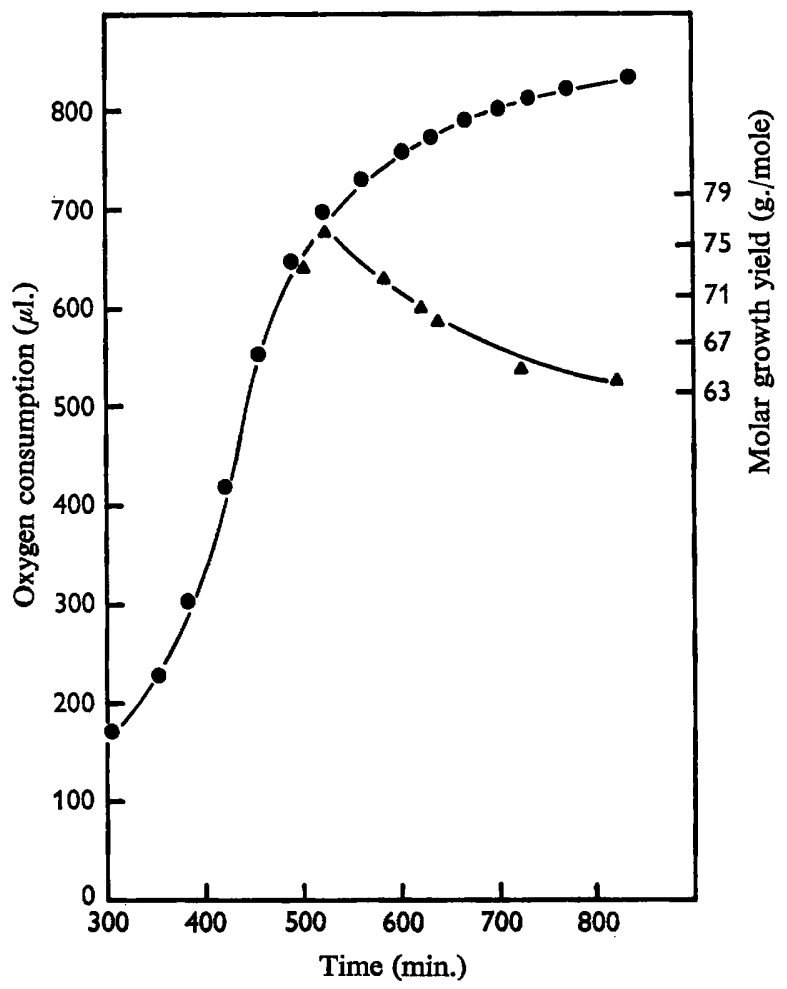

Fig. 3. The relation between oxygen consumption, period of growth and molar growth yield for cultures of $P$. aeruginosa grown on $4 \mathrm{~mm}$ glucose at $37^{\circ}$., , oxygen consumption; $\Lambda$, molar growth yield.

Table 3. Growth of Pseudomonas aeruginosa on $\left[U-{ }^{14} \mathrm{C}\right]$ glucose at $30^{\circ}$ and $37^{\circ}$

\begin{tabular}{|c|c|c|c|c|}
\hline \multirow[b]{2}{*}{ Radioactive fraction } & \multicolumn{2}{|c|}{$30^{\circ}$} & \multicolumn{2}{|c|}{$37^{\circ}$} \\
\hline & $\mathbf{A}$ & B & $\mathbf{A}$ & B \\
\hline Total counts $(a)$ & $1,623,000$ & 100 & $\mathrm{I}, 668,000$ & 100 \\
\hline Cells + supernatant $(b)$ & 919,700 & $56 \cdot 7$ & 931,300 & $55 \cdot 8$ \\
\hline Supernatant $(c)$ & 92,300 & $5 \cdot 7$ & I I I, 800 & $6 \cdot 7$ \\
\hline Cells $(b-c)$ & 827,400 & $5 \pi \cdot 0$ & 819,500 & $49 \cdot \mathrm{I}$ \\
\hline Carbon dioxide $(a-b)$ & 703,300 & $43 \cdot 3$ & 736,700 & 44.2 \\
\hline
\end{tabular}

Column A: counts $/ \mathbf{1 2} \cdot 5 \mathrm{ml}$. medium $/ \mathrm{min}$.

Column B: percentage of total counts present.

For growth at $30^{\circ}$, the specific activity of glucose was 31,100 counts $/ \mathrm{min} . / \mu$ mole and for growth at $37^{\circ}, 32,800$ counts $/ \mathrm{min} . / \mu$ mole.

The molar growth yield (g./mole measured turbidimetrically) was 77 at $30^{\circ}$ and 75.5 at $37^{\circ}$. 
to determine whether there was appreciable excretion of materials into the growth medium, the organism was grown at $30^{\circ}$ and $37^{\circ}$ in the presence of $\left[\mathrm{U}-{ }^{14} \mathrm{C}\right]$ glucose (Table 3). The results agree well with the data from the manometric experiments and show only small amounts of radioactive material in the culture supernatant. In view of its low amount, the nature of this material was not further investigated.

\section{DISCUSSION}

Our results indicate that when Pseudomonas aeruginosa is grown on limiting glucose or gluconate almost identical molar growth yields are obtained. In contrast with the observations of Campbell et al. (1956), the molar growth yield with limiting 2-oxogluconate is significantly less. A direct comparison with the work of Campbell et al. is not possible as their growth data were recorded $(a)$ as a percentage of light transmission, and (b) as $\mathrm{mg}$. protein per $100 \mathrm{ml}$. of medium. However, in a later paper, Warren, Ells \& Campbell (1960) recorded a protein content of $57 \%$ for the organism when grown on $0.2 \%$ glucose, the concentration used in the earlier growth yield work. At $0.2 \%$ glucose, Campbell et al. reported a growth yield of $24 \mathrm{mg}$. protein per $100 \mathrm{ml}$. medium from which it is possible to calculate a molar growth yield of 37.8 , a value approximately one half the figure reported here. $Y_{\text {glucose }}$ values have been measured for a number of bacteria grown aerobically in simple medium and have been found to fall in the range 70-90 (e.g. Morris,I960; Whitaker, I962; Hadjipetrou, Gerrits, Teulings \& Stouthamer, 1964). The $Y_{\text {glacose }}$ value reported here for $P$. aeruginosa is thus within this range whereas the figure calculated from the data of Campbell et al. is much lower.

In considering the relative metabolic importance of the various pathways of glucose degradation, the fact that glucose and gluconate give similar growth yields indicates that they are probably metabolized by pathways which yield identical amounts of ATP and metabolic intermediates. This would happen if glucose was metabolized to 6-phosphogluconate via gluconate and if the oxidative step from glucose to gluconate was energetically wasteful to the organism. Supporting this concept is the observation that the $\mathrm{Y}_{\mathrm{O}_{2}}$ value for gluconate is higher than that for glucose, indicating that a portion of glucose oxidation by the organism is wasteful as regards energy production. The lower molar growth yield with 2-oxogluconate could be interpreted as follows: 2-oxogluconate is phosphorylated to 2-0xo-6-phosphogluconate and then, by analogy with the system operative in Pseudomonas fluorescens (Frampton \& Wood, 196I), reduced in a nicotinamide nucleotide-coupled reaction to 6-phosphogluconate. Biologically available energy occurs in two forms, ATP and reduced nicotinamide nucleotides, and, since 2-oxogluconate has an energy requirement to initiate its metabolism quite separate from the ATP which all three substrates require for their kinase-mediated phosphorylation, this may explain why $Y_{2 \text {-oxogluconate }}$ is less than $Y_{\text {glucose }}$ and $Y_{\text {gluoonate. }}$ The other possibility, that glucose and gluconate are mainly oxidized via 2-oxogluconate, could only be accepted if there was significant ATP production during the oxidation of gluconate to 2-oxogluconate. This seems unlikely since Ramakrishnan \& Campbell (1955) could not detect conventional coenzyme requirements for partially purified gluconic acid dehydrogenase from $\boldsymbol{P}$. aeruginosa.

This interpretation of the results may not, however, be quite as simple, since it does not take into account the presence of hexokinase and gluconic acid dehydrogenase in 
extracts of glucose-grown cells. The $Y_{\mathrm{O}_{3}}$ value for 2-oxogluconate is higher than the corresponding gluconate value, indicating the possibility of some uncoupled oxidation with gluconate as well as with glucose.

Molar growth yield determinations were carried out with all three substrates at $30^{\circ}$ and $37^{\circ}$ to investigate the possibility of a greater maintenance energy requirement by the cells at the higher temperature. Since the $Y$ values for each substrate were indistinguishable at the two temperatures we conclude that this is not the case. Senez (1962) reached a similar conclusion for Aerobacter aerogenes grown aerobically on glucose at various temperatures between $23^{\circ}$ and $37^{\circ}$.

An interesting feature of the methodology of carrying out molar growth yield determinations in the Warburg apparatus when simultaneous measurement of oxygen consumption is required, is the long lag periods which we encountered with KOH in the centre well. Belief that this could be caused by a $\mathrm{CO}_{2}$ deficiency led us to substitute a solution based on the $\mathrm{CO}_{2}$-buffer of Pardee (I949), which ensures the maintenance of a partial pressure of $\mathrm{CO}_{2}$ in the atmosphere; the lag periods were then eliminated. This prodecure would seem to be of general applicability for measurements of this type.

We are grateful to the Medical Research Council for the award of a Scholarship for Training in Research Methods to I. MacK.

\section{REFERENCES}

BAUCHOP, T. \& ELSDEN, S. R. (1960). The growth of micro-organisms in relation to their energy supply. J. gen. Microbiol. 23, 457.

CAmpbell, J. J. R., Ramakrishnan, T., Linnes, A. G. \& EAGles, B. A. (1956). Evaluation of the energy gained by Pseudomonas aeruginosa during the oxidation of glucose to 2-ketogluconate. Can. J. Microbiol. 2, 304.

ClardDGe, C. A. \& WerkMAN, C. H. (1953). Formation of 2-ketogluconate from glucose by a cellfree preparation of Pseudomonas aeruginosa. Arch. Biochem. Biophys. 47, 99.

Claridge, C. A. \& Werkman, C. H. (1954). Evidence for alternate pathways for the oxidation of glucose by Pseudomonas aeruginosa. J. Bact. 68, 77.

DE LEY, J. (1960). Comparative carbohydrate metabolism and localization of enzymes in Pseudomonas and related micro-organisms. J. appl. Bact. 23, 400.

Frampton, E. W. \& Wood, W. A. (I961). Carbohydrate oxidation by Pseudomonas fluorescens. VI. Conversion of 2-keto-6-phosphogluconate to pyruvate. J. biol. Chem. 236, 257 I.

Grado, C. \& Ballou, C. E. (I96r). Myo-inositol phosphates obtained by alkaline hydrolysis of beef brain phosphoinositide. J. biol. Chem. 236, 54 .

HadjIPetrou, L. P., Gerrits, J. P., Teulings, F. A. G., \& Stouthamer, A. H. (I964). Relation between energy production and growth of Aerobacter aerogenes. J. gen. Microbiol. 36, 139.

JoHNson, M. J. (1949). A rapid micromethod for estimation of non-volatile organic matter. J. biol. Chem. x81, 707.

MORRIS, J. G. (1960). Studies on the metabolism of Arthrobacter globiformis. J. gen. Microbiol. 22 564.

PARDEe, A. B. (1949). Measurement of oxygen uptake under controlled pressures of carbon dioxide. J. biol. Chem. 179, 1085.

Ramakrishnan, T. \& CAMPBell, J. J. R. (1955). Gluconic dehydrogenase of Pseudomonas aeruginosa. Biochim. biophys. Acta I7, 122.

SENEZ, J. C. (1962). Some considerations on the energetics of bacterial growth. Bact. Rev. 26, 95.

SMITH, I. (I96I). In Chromatographic and Electrophoretic Techniques, vol. I, p. 246. Ed. by I. Smith. London: W. Heinemann Ltd. 
Warren, R. A. J., Ells, A. F. \& Campbell, J. J. R. (1960). Endogenous respiration of Pseudomonas aeruginosa. J. Bact. 79, 875.

WhitAKER, A. M. (1962). The growth of micro-organisms in relation to their energy supply. Ph.D. Thesis. University of Sheffield.

WhITAKER, A. M. \& ELSDEN, S. R. (1963). The relation between growth and oxygen consumption in micro-organisms. J. gen. Microbiol. 3r, xxii. 